\title{
Analysis of Salt Production, Consumption and Import in Indonesia
}

\author{
Ziecky Mardoni \\ Universitas Putra Indonesia YPTK Padang, Indonesia \\ Email: zieckymardoni@upiyptk.ac.id
}

\begin{abstract}
This study aims to analyze and determine the effect of (1) consumption, capital, and labor on salt production in Indonesia (2) production, salt prices, imports, and Gross Domestic Product on salt consumption in Indonesia (3) consumption, exchange rates, and Gross Domestic Product on imports salt in Indonesia. This type of research is descriptive and associative. While this type of data is documentary data, the source of information is secondary data and data in the form of time series from 1986 - 2018. Simultaneous equation model analysis tools with the Two Stages Least Squared (TSLS) method. This study concludes that consumption of salt, capital, and labor has a significant influence on salt production in Indonesia. Salt production, salt prices, salt imports, and Gross Domestic Product significantly influence salt intake. Salt consumption and Gross Domestic Product have a significant effect on salt imports in Indonesia. Based on these results, the policy suggested is that the Government, through the Ministry of Agriculture, must issue a policy to encourage capital increase for salt production activities. In addition, the Government is also expected to increase the quantity and quality of workers who work in the industry so that the production of salt itself can be improved.
\end{abstract}

Keyword: Analysis, Salt Production, Consumption, Import.

\section{A. INTRODUCTION}

Salt is one of Indonesia's strategic commodities where its use is not only for human consumption but also as industrial raw material and salting, and various foods (Guntur et al., 2018; Peng et al., 2019). Even so, the national salt production (households and companies) is still not sufficient to meet the national salt consumption (families and companies), so imports of salt (households and companies) cannot be avoided. This condition can be seen in Table 1:

Table 1. Development of National Salt Production, Consumption and Import in

Indonesia from Year 2011-2018

\begin{tabular}{|c|c|c|c|}
\hline Year & $\begin{array}{c}\text { Salt Production } \\
\text { National (Tons) }\end{array}$ & $\begin{array}{c}\text { National Salt } \\
\text { Consumption (Tons) }\end{array}$ & $\begin{array}{c}\text { National Salt Import } \\
\text { (Tons) }\end{array}$ \\
\hline 2011 & $1,352,400$ & $2,706,300$ & $1,661,488$ \\
\hline 2012 & $1,199,000$ & $2,742,000$ & $1,657,548$ \\
\hline 2013 & $1,371,000$ & $2,783,250$ & $1,701,418$ \\
\hline 2014 & $1,230,600$ & $2,870,000$ & $2,083,343$ \\
\hline 2015 & $1,113,118$ & $3,405,000$ & $2,835,871$ \\
\hline 2016 & 168,054 & $3,601,000$ & $2,997,998$ \\
\hline 2017 & $1,102,007$ & $3,663,000$ & $2,201,102$ \\
\hline 2018 & $2,716,000$ & $3,711,000$ & $3,700,010$ \\
\hline Average & $\mathbf{1 , 2 8 1 , 5 2 2}$ & $\mathbf{3 , 1 8 5 , 1 9 4}$ & $\mathbf{2 , 3 5 4 , 8 4 7}$ \\
\hline
\end{tabular}

Source: Ministry of Industry, 2018 
The table shows that the average national salt production is $1,281,522$ tons, while the average national salt consumption is $3,185,194$ tons. This means that national salt production cannot meet national salt consumption, so imports must meet the need for national salt consumption. On average, national salt imports reached 2,354,847 tons.

Table 2. Development of Production, Capital and Labor in Indonesia from the Year 2011-2018

\begin{tabular}{|c|c|c|c|c|c|c|}
\hline Year & $\begin{array}{c}\text { Salt } \\
\text { Production } \\
\text { National } \\
\text { (Tons) }\end{array}$ & $\begin{array}{c}\text { Development } \\
\mathbf{( \% )}\end{array}$ & $\begin{array}{c}\text { Capital } \\
\text { (Million } \\
\text { Rupiah) }\end{array}$ & $\begin{array}{c}\text { Development } \\
\mathbf{( \% )}\end{array}$ & $\begin{array}{c}\text { Labor } \\
\text { (Person) }\end{array}$ & $\begin{array}{c}\text { Development } \\
\text { (\%) }\end{array}$ \\
\hline 2011 & $1,352,400$ & - & $2,433,863,51$ & - & $1,593,09$ & - \\
\hline 2012 & $1,199,000$ & -11.34 & $2,882,044,66$ & 18.41 & $1,619,39$ & 1.65 \\
\hline 2013 & $1,371,000$ & 14.35 & $3,400,812,70$ & 18.00 & $1,629,10$ & 0.60 \\
\hline 2014 & $1,230,600$ & -10.24 & $3,924,537,85$ & 15.40 & $1,634,81$ & 0.35 \\
\hline 2015 & $1,113,118$ & -9.55 & $4,481,822,23$ & 14.20 & $1,638,24$ & 0.21 \\
\hline 2016 & 168,054 & -84.90 & $521,658,71$ & -88.36 & 365,16 & -348.64 \\
\hline 2017 & $1,102,007$ & 555.75 & $2,796,668,21$ & 436.11 & $1,003,11$ & 174.70 \\
\hline 2018 & $2,716,000$ & 146.46 & $4,900,223,34$ & 75.22 & $1,813,21$ & 80.76 \\
\hline
\end{tabular}

Source: Ministry of Industry and Central Statistics Agency

Table 2 shows the development of production, capital, and labor in the salt industry in Indonesia from 2011-2018. In the table, it can be seen that the highest growth of salt production occurred in 2018, which was $146.46 \%$, not in 2017 , the increase in the development of salt production in 2017 was only due to a decrease in salt production in 2016, production in 2016 fell sharply due to anomalies. La Nina weather triggers the emergence of a wet drought that inhibits salt production. The high development of national salt production in 2018 is thought to be influenced by the increase in capital and labor as factors that influence it. In 2018, capital experienced a decline in development from $436.11 \%$ in 2017 to $75.22 \%$. Likewise, the workforce also experienced a decrease in development to $80.76 \%$ from the previous $174.70 \%$.

Table 3. National Salt Consumption, Salt Price and Gross Domestic Product in Indonesia 2011-2018

\begin{tabular}{|c|c|c|c|c|c|c|}
\hline Year & $\begin{array}{c}\text { Consumption } \\
\text { National } \\
\text { (Tons) }\end{array}$ & $\begin{array}{c}\text { Development } \\
\mathbf{( \% )}\end{array}$ & $\begin{array}{c}\text { Salt Price } \\
\text { (IDR/Kilogram) }\end{array}$ & $\begin{array}{c}\text { Development } \\
\mathbf{( \% )}\end{array}$ & $\begin{array}{c}\text { Gross } \\
\text { Domestic } \\
\text { Product } \\
\text { (Billion IDR) }\end{array}$ & $\begin{array}{c}\text { Development } \\
\text { (\%) }\end{array}$ \\
\hline 2011 & $2,706,300$ & 2,05 & 778 & - & $7,831,726$ & - \\
\hline 2012 & $2,742,000$ & 1,32 & 764 & -1.8 & $8,615,704$ & 10.01 \\
\hline 2013 & $2,783,250$ & 1,50 & 755 & -1.2 & $9,546,134$ & 10.80 \\
\hline 2014 & $2,870,000$ & 3,12 & 768 & 1.7 & $10,569,705$ & 10.72 \\
\hline 2015 & $3,405,000$ & 18,64 & 763 & -0.7 & $11,531,717$ & 9.10 \\
\hline 2016 & $3,601,000$ & 5,76 & 1,500 & 96.6 & $12,406,809$ & 7.59 \\
\hline 2017 & $3,663,000$ & 1,70 & 765 & -0.5 & $13,588,807$ & 9.53 \\
\hline 2018 & $3,741,000$ & 2,13 & 767 & 0.3 & $14,837,477$ & 9.19 \\
\hline
\end{tabular}

Source: Ministry of Industry and Central Statistics Agency 
The need for salt from year to year is increasing in line with Indonesia's population growth and industrial development. Table 3 shows the effect of national salt consumption, salt prices, and Gross Domestic Product in Indonesia from 20112018. In the table, it can be seen that the national salt consumption experienced the lowest development occurred in 2012 at 1.32\%. This decline is thought to have been caused by rising salt prices and falling Gross Domestic Product. However, the table shows that the cost of salt decreased to $-1.8 \%$, and Gross Domestic Product increased to $10.01 \%$.

Table 4 shows the development of national salt imports and their factors. The table shows that the highest growth of salt imports occurred in 2018 at $68.09 \%$. This increase in salt development is influenced by the appreciation of the exchange rate and the increase in Gross Domestic Product (Sudaryana \& Pramesti, 2018; Wang et al.,2019). The table shows that the exchange rate depreciated, and Gross Domestic Product did experience a slight decline in development from 9.53\% to $9.18 \%$.

Table 4. Import of Salt, Exchange Rate and Gross Domestic Product in Indonesia 2011-2018

\begin{tabular}{|c|c|c|c|c|c|c|}
\hline Year & $\begin{array}{c}\text { Salt } \\
\text { Import } \\
\text { National } \\
\text { (Tons) }\end{array}$ & $\begin{array}{c}\text { Development } \\
\text { (\%) }\end{array}$ & $\begin{array}{c}\text { Exchange } \\
\text { rate } \\
\text { (IDR/USD) }\end{array}$ & $\begin{array}{c}\text { Development } \\
\text { (\%) }\end{array}$ & $\begin{array}{c}\text { Gross Domestic } \\
\text { Product } \\
\text { (Billion IDR) }\end{array}$ & $\begin{array}{c}\text { Development } \\
\text { (\%) }\end{array}$ \\
\hline 2011 & $1,661,488$ & - & 9,068 & - & $7,831,726$ & - \\
\hline 2012 & $1,657,548$ & -0.24 & 12,189 & 34.42 & $8,615,704$ & 10.10 \\
\hline 2013 & $1,701,418$ & 2.65 & 12,440 & 2.06 & $9,546,134$ & 10.80 \\
\hline 2014 & $2,083,343$ & 22.45 & 12,573 & 1.07 & $10,569,705$ & 10.72 \\
\hline 2015 & $2,835,871$ & 36.12 & 13,271 & 5.55 & $11,531,717$ & 9.10 \\
\hline 2016 & $2,997,998$ & 5.72 & 13,307 & 0.27 & $12,406,809$ & 7.59 \\
\hline 2017 & $2,201,102$ & -26.58 & 13,384 & 0.57 & $13,588,807$ & 9.53 \\
\hline 2018 & $3,700,010$ & 68.09 & 13,882 & 3.72 & $14,837,477$ & 9.18 \\
\hline
\end{tabular}

Source: Ministry of Industry, Central Statistics Agency and Bank Indonesia

Based on the phenomena and conditions above to determine the extent of the influence of the factors that influence the production, consumption, and import of salt in Indonesia, the authors are interested in studying it in the form of research with the title "Analysis of Production, Consumption, and Import of Salt in Indonesia."

\section{B. LITERATURE REVIEW}

\section{Consumption Theory}

Keynes's consumption function can be seen in Figure 1; the Keynes consumption function in Figure 1 shows the consumption function with three reasons that Keynes suspected. First, the marginal propensity to consume c is between zero and one (Kerdan et al.,2019; Santos et al.,2019). Second, the average propensity to consume decreases as income rises. Third, consumption is determined by current income. 


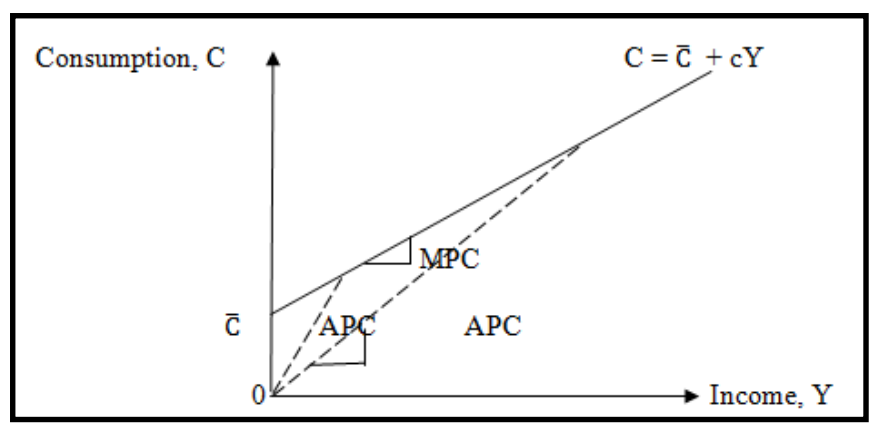

Figure 1. Keynesian Consumption Function

Source: Mankiw (2003)

In Figure 1, it can be seen that the Keynes consumption function does not pass through point 0 but through the vertical axis at a positive value (Co). As a consequence of this consumption function, an increase in national income will impact a decrease in the average consumption desire or APC. If the APC decreases with an increase in national income, in the Keynes consumption function, it will be seen; first, an increase in revenue is still followed by the rise in consumption; secondly, when the consumption line C crosses the OY line, the rise in income is accompanied by a decrease in consumption or APC (Nayar, 2019; Liu et al., 2020).

From Keynes's theory above, it can be concluded that income is a determinant of consumption. In other words, an increase in income will increase individual or household consumption.

\section{Production Theory}

According to Debertin (2012), the production function describes the technical relationship that transforms inputs (resources) into outputs (commodities). Mathematicians define a function as a rule for assigning each value in a set of variables (domain) to a single value of another set of variables that are the range of the function. Generally, the function is written mathematically as follows:

$$
\mathrm{Y}=\mathrm{f}(\mathrm{X})(1)
$$

Where $\mathrm{Y}$ is the output and $\mathrm{X}$ is the input. The function's domain is all $\mathrm{x}$ values greater than or equal to zero. The function range consists of the output level (Y) obtained from each input level $(X)$.

Meanwhile, according to Burkett (2006) and Rusdi (2018), the production function is an equation that describes the maximum output that may be produced with various combinations of inputs. In general, the production function represents the net output or value-added of these multiple combinations. Based on this opinion, it can be seen that the production function is the relationship between inputs and results in the production process.

\section{Import Theory}

According to Dorbusch (2008), a country's imports are influenced by the exchange rate (exchange rate) and real domestic income. Domestic implications can 
be symbolized as $\mathrm{Mt}$, concerning the number of foreign-made goods demanded by the domestic population, which is influenced by the relative price of foreign goods (E) and domestic real income $Y$, which can be written mathematically as follows:

$$
\mathrm{Mt}=\mathrm{f}(\mathrm{E}, \mathrm{Y})
$$

Suppose the relative price of foreign goods (E) increases. In that case, the domestic population will shift spending on foreign goods into domestic goods, and if real domestic income increases, then part of that domestic income will be spent on buying foreign goods, which means that domestic imports will increase (Abdullah \& Shalihati, 2020; Sulistyaningsih \& Alighiri, 2018; Muhandhis et al.,2019).

Meanwhile, according to Krugman (2005), imports are influenced by the exchange rate (exchange rate) and domestic income.

$$
\mathrm{M}=\mathrm{f}(\mathrm{E}, \mathrm{Y})
$$

Where:

$\mathrm{M}=$ Import

$\mathrm{E}=$ Exchange Rate (Exchange Rate)

$\mathrm{Y}=$ Domestic Income

If the exchange rate and income change, it will affect the change in imports. If the exchange rate or exchange rate of a country appreciates (its value increases relative to other currencies), the price of imported goods in a country will decrease, so that country's imports will increase.

\section{Previous Research}

The previous research related to the author's research is by Orazem (2011) and Dwiyitno et al. (2021), who found a causal relationship between sugar production, consumption, and imports in several OECD countries. In addition, capital and labor have a significant effect on sugar production. On the other hand, prices and income of Gross Domestic Product also substantially impact sugar consumption in several OECD countries (Helmi \& Sasaoka, 2018; Yani et al.,2019). Then, the exchange rate and output also significantly impact sugar imports in several OECD countries.

The following study was by Alordman (2012) and Purwanti et al. (2020). They found that the relationship between total production, consumption, and imports had a significant effect on the economic performance of developing countries. Furthermore, capital and labor have a substantial impact on the total production of developing countries, and prices, disposable income, and interest rates significantly affect the total consumption of developing countries. Then, the exchange rate and national income substantially affect the total imports of developing countries.

\section{Hypothesis}

Based on the formulation of the problem and the explanation of the conceptual framework, a hypothesis can be found in this study, which is a provisional assumption to answer the research objectives. 
The hypotheses proposed are as follows:

1. Consumption, capital, and labor significantly affect salt production in Indonesia.

Ho: $\lambda_{1}=\lambda_{2}=\lambda_{3}=0$

Ha: $\lambda_{1} \neq \lambda_{2} \neq \lambda_{3} \neq 0$

2. Salt production, salt prices, Gross Domestic Product, and salt imports significantly affect salt consumption in Indonesia.

Ho: $\alpha_{1}=\alpha_{2}=\alpha_{3}=\alpha_{4}=0$

Ha: $\alpha_{1} \neq \alpha_{2} \neq \alpha_{3} \neq \alpha_{4} \neq 0$

3. Salt consumption, exchange rate, and Gross Domestic Product significantly affect salt imports in Indonesia.

Ho: $\beta_{1}=\beta_{2}=\beta_{3}=0$

Ha: $\beta_{1} \neq \beta_{2} \neq \beta_{3} \neq 0$

\section{METHOD}

This analysis aims to describe each variable into a frequency distribution table, then perform a percentage analysis and provide an interpretation of the analysis. As well as calculating the descriptive statistical components of each variable. Following the formulation of the problem and the objectives of this research, this research is classified as descriptive and associative research. Descriptive research is research that aims to describe or explain something as it is. In this study, it is seen how much influence the causal variable has on the effect variable. Associative research is research that aims to see the relationship between independent variables. This research is also ex post facto, that is, research that seeks to find out what causes something to happen and sort it backward so that the causal factors are known.

The type of data in this study is documentary data. Documentary data is data that specific agencies have published. At the same time, the source of data in this study is secondary data. Secondary data is research data that is not obtained directly but through intermediary media (obtained and recorded by other parties) (Warsito \& Triadi, 2020). At the same time, the form of data is time series. Time series data consists of one variable but covers several periods. The data for all variables in this study started from 1986 to 2018, with 33 years of data. Data collection techniques are the methods used to obtain research data. The data used in this study is secondary data obtained from related institutions or agencies, such as monthly reports and annual reports from BPS (Central Bureau of Statistics) Indonesia in various editions. Testing the data using several test techniques, including Stationary Test, Cointegration Test, Granger Causality Test, Analysis Model, and Hypothesis Testing (T-Test and F-Test). 


\section{RESULT AND DISCUSSION}

\section{Stationary Test}

To test the feasibility of the model, in the time series data analysis, a test is conducted on the stationary of the data to avoid spurious/nonsense regression problems. For this reason, an investigation is carried out whether the time series data used in this analysis has been integrated. This test is carried out using the unit root test (Gujarati, 2004; Ningrum et al., 2018).

Table 5. Stationary Test Results of Each Variable

\begin{tabular}{|c|c|c|}
\hline Variable Name & Level & Probability Value \\
\hline Salt Production $(\mathrm{SP})$ & $1^{\text {st }}$ difference & 0.0001 \\
\hline Salt consumption $(\mathrm{SC})$ & $1^{\text {st }}$ difference & 0.0000 \\
\hline Salt Import $\left(\mathrm{X}_{1}\right)$ & $1^{\text {st }}$ difference & 0.0000 \\
\hline Capital $(\mathrm{C})$ & $2^{\text {nd }}$ difference & 0.0000 \\
\hline Labor $(\mathrm{L})$ & $2^{\text {nd }}$ difference & 0.0017 \\
\hline Price Salt $(\mathrm{PS})$ & $1^{\text {st }}$ difference & 0.0011 \\
\hline Exchange rate $(\mathrm{E})$ & $1^{\text {st }}$ difference & 0.0000 \\
\hline Gross Domestic Product $(\mathrm{Y})$ & $2^{\text {nd }}$ difference & 0.0000 \\
\hline
\end{tabular}

Source: The Results of Data Processing with Eviews 6, $\mathrm{n}=33 \alpha=0,05$

The variables of capital and labor are stationary at the 2 nd difference because these variables have a small probability value of $=0.05$ at the 2 nd difference. Because all variables in this study are inactive, all variables in this study can be said to be average, variance, and autocovariance constant from time to time (for different lags, the values are the same, it doesn't matter where to start measuring).

Time-series data is stationary if the mean, variance, and autocovariance are constant over time (for different lags, the values are the same, no matter where you start measuring). In short, the three measures are independent of time ( $t$ ) or, in the literature, called time-invariant. In time series analysis, whether the data is stationary is very important. Economic variables that continue to increase over time are examples of variables that are not stationary; in estimating the regression coefficient, including non-stationary variables in the equation causes the resulting standard error to be biased. This bias causes the conventional criteria to justify causality between two variables to be invalid. Suppose a variable has a unit root (non-stationary); in most cases, including non-stationary variables in the regression analysis results in incorrect conclusions. It is found that the estimated coefficient is significant, but there is no relationship at all (spurious regression) (Sinaga, 2018).

Table 5 describes each static variable at a certain level, namely at the 1 st difference or 2 nd difference. The table shows that the variables of salt production, salt consumption, salt imports, salt prices, exchange rates, and Gross Domestic Product have a small probability value of $=0.05$ at the 1 st difference. Therefore, these variables are stationary at the 1 st difference. 


\section{Cointegration Test}

If the regression of a non-stationary variable to another non-stationary variable (or stationary to a different degree) is performed, it will result in a spurious regression. And suppose each dependent and independent variable is not static. In that case, it is still included as a variable in the regression analysis. There is a possibility that the independent and dependent variables seem to influence each other, but in fact, each independent variable and dependent variable move independently (spurious relationship) (Pratama, 2018; Samir \& Saleh, 2018).

For these non-stationary variables to still be included in the regression model, a test must first be carried out which truly concludes that it is true that the independent variable affects the dependent variable in this case, for example, the economic growth variable (Y1) explains or affects HDI variable movement (Y2). According to Gujarati (2003), regression of non-stationary variables to other nonstationary variables can still be done as long as in the long term the relationship or balance between these variables or, in other words, the variables are cointegrated. Therefore, for non-stationary data, cointegration testing is necessary. For example, the variables of human development index (IPMA) and economic growth (Yt) contain a unit root or are not stationary. From Table 6 it can be seen that in the equation $\mathrm{D}(\mathrm{UKG})=\mathrm{UKG}(-1), \mathrm{D}(\mathrm{UPG})=\mathrm{UPG}(-1)$ and $\mathrm{D}(\mathrm{UIG})=\mathrm{UIG}(-1)$ has a small probability of $=0.05$.

Table 6. Cointegration Test Results

\begin{tabular}{|l|c|c|c|c|}
\hline \multicolumn{1}{|c|}{ Equality } & Coefficient & Std. Error & t-Statistic & Probability \\
\hline D(UKG) = UKG(-1) & -0.480288 & 0.162013 & -2.964496 & 0.0058 \\
\hline D(UPG) = UPG(-1) & -0.713795 & 0.184862 & -3.861227 & 0.0005 \\
\hline D(UIG) = UIG(-1) & -0.610670 & 0.176447 & -3.460927 & 0.0016 \\
\hline
\end{tabular}

Source: The Results of Data Processing with Eviews 6, $\mathrm{n}=33 \alpha=0,05$

Therefore, each equation in this study is cointegrated or explains each other. In other words, even though all the variables in each equation in this study are not stationary, all the variables in each equation have a long-term relationship or balance between these variables. Thus the equation no longer contains spurious regression problems.

\section{Granger Causality Test}

This test, in essence, can indicate whether a variable has a two-way relationship or only one direction (Nachrowi, 2006: 262). Mathematically, to see whether $X$ causes $Y$ or not, there are several steps:

a. $\mathrm{H}_{0}: \mathrm{Y} 1$ does not cause $\mathrm{Y} 2$

In regression, this means that all regression coefficients are 0 , so the hypothesis can also be written as:

$\mathrm{H}_{0}: \beta_{1}=\beta_{1}=\beta_{3}=\ldots .=\beta_{4}=0$

b. Make a full regression and get Sum Square of Error (SSE)

$\mathrm{Y} 1=\Sigma \alpha_{\mathrm{i}} \mathrm{Y}_{\mathrm{t}-\mathrm{i}}+\Sigma \beta_{\mathrm{i}} \mathrm{Y}_{\mathrm{t} 2-\mathrm{i}}+\varepsilon_{\mathrm{t}}$ 
c. Make a limited regression and get it anyway Sum Square of Error (SSE) $\mathrm{Y}_{1}=\sum \alpha_{\mathrm{i}} \mathrm{Y}_{\mathrm{t} 2-\mathrm{i}}+\varepsilon \mathrm{t}$

d. Perform the $\mathrm{F}$ test based on the obtained SSE, with the formula:

$$
\mathrm{F}=\left(\frac{\mathrm{N}-\mathrm{k}}{\mathrm{q}}\right)\left(\frac{\mathrm{SSE}_{\text {limited }}-\mathrm{SSE}_{\mathrm{full}}}{\mathrm{SSE}_{\mathrm{full}}}\right)
$$

Where:

$\mathrm{N}=$ many observations

$\mathrm{k}=$ number of full model parameters

$\mathrm{q}=$ the number of model parameters is limited

$\mathrm{e}=$ If $\mathrm{H} 0$ is rejected, it means that $\mathrm{C}$ affects $\mathrm{Y}$.

To find out whether $\mathrm{H} 0$ is rejected or accepted, a probability test (t-statistic) is carried out. If the probability value is small than $=0.05$ (t-statistic is more significant than t-table), Ho is rejected or Ha is accepted, which means Y1 affects Y2. Vice versa.

The same way can also be done to see if $\mathrm{Y} 1$ affects $\mathrm{Y} 2$. Ut $=$ error value with a particular value of Y1t.

\section{Table 7. Granger Causality Test Results Salt Production and Salt Consumption}

\begin{tabular}{|c|c|c|}
\hline Null Hypothesis & F-Statistic & Probability \\
\hline PG does not Granger Cause KG & 8.00287 & 0.0000 \\
KG does not Granger Cause PG & 9.17915 & 0.0000 \\
\hline
\end{tabular}

Source: the results of data processing with Eviews 6, $\mathrm{n}=33, \alpha=0,05$

From the results of the Granger Causality test in Table 7, it is obtained that each probability value of salt production (PG) on salt consumption (KG) or salt consumption $(\mathrm{KG})$ on salt production $(\mathrm{PG})$ is small from $=0.05$. The meaning of the word salt production, variables on salt consumption have a two-way relationship or influence each other.

\section{Salt Production Equation Model}

Appendix 1 shows the results of the estimation of the salt production equation. From the estimates that have been made, the equation model for salt production is as follows: $\log P G=1.261 .440+0,798453 \log K G+0.400753 \log \mathrm{M}+$ 0.170514 Log TK... (4)

The first hypothesis in this study proved to be accepted. In other words, salt consumption, capital, and labor significantly affect salt production in Indonesia. Partially, salt consumption has a significant and positive effect on salt production in Indonesia. The presence of a substantial influence between salt consumption on salt production indicates that salt production is influenced by salt consumption. This effect is because when salt consumption increases, this condition means an increase in demand for salt. This increase in demand signals entrepreneurs to increase production to maximize profits.

Partially, capital has a significant and positive effect on salt production in Indonesia. In this study, the money can be seen from the means used for the salt production process in Indonesia. The existence of capital will certainly be able to drive production activities. Without capital, production activities cannot be said to 
take place. High money will make the industry more flexible in carrying out production activities because it has financial support, the availability of machines and equipment, and a place of business. Therefore, a capital increase will increase the amount of salt present.

Partially, labor affects salt production in Indonesia significantly and positively. Following the Cobb-Douglas theory of production, delivery is one of the production inputs. The existence of delivery will undoubtedly be able to drive production activities. Without a workforce, production activities can certainly take place. Machinery, raw materials, and other equipment in the production process cannot be processed without the assistance of workers. Like capital and raw materials, labor also contributes or contributes significantly to the production of salt in Indonesia. This is because salt production is highly dependent on sweat, and even its role is more significant than capital and raw materials.

\section{Salt Consumption Equation Model}

Appendix 2 shows the results of estimating the effect of salt production, salt imports, prices, and per capita income on salt consumption in Indonesia. From the estimation results that have been carried out, the equation model for salt consumption is as follows: $\log K G=114.873,6+0,575353$ Log PG + 0,703363 Log IG $0.390444 \log \mathrm{H}+0.112974 \mathrm{Y}$

The second hypothesis in this study proved to be accepted. This means that salt production, salt imports, salt prices, and Gross Domestic Product significantly affect salt consumption in Indonesia. Partially, salt production has a significant and positive effect on salt consumption in Indonesia. Salt production determines the rise and fall of salt consumption with the word's meaning. This is because when salt production increases, the price of salt will decrease. The decline in the price of salt has made people's purchasing power of salt increase. This situation will eventually increase salt consumption.

Partially, salt imports have a significant and positive impact on salt consumption in Indonesia. The increase in salt imports assumes that an increase in salt production does not accompany it; this condition will increase salt consumption. This is because the rise in salt imports will increase the supply of salt in the market so that the price of salt will decrease. This decrease in the price of salt will cause an increase in people's purchasing power for salt. Therefore, this will increase salt consumption.

Partially, the price of salt has a significant and negative effect on salt consumption in Indonesia. If the cost of salt increases, the community's sacrifice to buy salt will also increase to reduce purchasing power. Of course, this condition will result in salt consumption also going down.

Partially Gross Domestic Product affects salt consumption in Indonesia significantly positively. The increase in Gross Domestic Product income will undoubtedly increase people's purchasing power in buying goods and services to 
satisfy their needs. This increase will encourage increased public consumption, one of which is salt as a basic need.

\section{Salt Import Equation Model}

Appendix 3 shows the results of the estimation of the salt import equation. From the estimates that have been made, the equation model for the import of salt is obtained as follows: $\log$ IG $=-526.059+0.553403 \log K G-0.010099 \log E+0.068985$ $\log Y \ldots(6)$

The third hypothesis in this study proved to be accepted. In other words, salt consumption, exchange rate, and Gross Domestic Product significantly affect salt imports.

Partially, salt consumption affects salt imports in Indonesia significantly and positively. This means that if salt consumption increases but is not matched by the rise in salt production, salt imports will increase. Because when the rise in salt imports does not drive the increased consumption of salt, there will be a shortage of salt in the market. Therefore, substances are needed.

Partially, the exchange rate has no significant effect on salt imports. This means that exchange rate fluctuations do not cause the ups and downs of salt imports. This condition is because salt is a basic need for the people of Indonesia. So even though the exchange rate depreciates, causing the price of imported goods to be expensive, people will still ask for salt. As of now, almost all food in Indonesia contains salt, so the demand for salt remains high.

Partially Gross Domestic Product affects salt imports significantly and positively in Indonesia. When Gross Domestic Product increases, imports will also increase, including implications of salt because the increase in Gross Domestic Product indicates an increase in national income so that national purchasing power also increases. Therefore, this increase will encourage increased imports.

\section{E. CONCLUSIONS}

The study results conclude that (1) Salt consumption, capital, and labor significantly affect salt production in Indonesia. In other words, if salt consumption, money, and labor increase, it will increase salt production in Indonesia; (2) Salt production, salt imports, salt prices, and Gross Domestic Product significantly affect salt consumption in Indonesia. This means that an increase in salt production, salt imports, and Gross Domestic Product and a decrease in salt prices will lead to an increase in salt consumption in Indonesia; and (3) Salt consumption and Gross Domestic Product have a significant effect on salt imports in Indonesia. In other words, if salt consumption and Gross Domestic Product increase, it will impact increasing salt imports in Indonesia. Meanwhile, the exchange rate has no significant effect on the rise and fall of salt imports in Indonesia. 


\section{REFERENCES}

1. Abdullah, A., \& Shalihati, F. (2020). The Effectiveness of the Salt Policy in Indonesia. Jurnal Manajemen \& Agribisnis, 17(3), 315-315.

2. Alordman, S. (2012). Impact of Production, Consumption, and Import to Economic Performance in Developing Countries. Journal of Economy and Society, 3(2), 224-261.

3. Burkett. (2006). Microeconomics with Production Function. The John Hopkins University Press, Baltimore.

4. Debertin, D. L. (2012). Agricultural Production Economics. Macmillan Publishing Company, New York.

5. Dornbusch, R., Stanley, F., \& Richard, S. (2008). Macroeconomics. Jakarta: Media Global Edukasi.

6. Dwiyitno, D., Sturm, M. T., Januar, H. I., \& Schuhen, K. (2021). Influence of various production methods on the microplastic contamination of sea salt produced in Java, Indonesia. Environmental Science and Pollution Research, 1-5.

7. Guntur, G., Jaziri, A. A., Prihanto, A. A., Arisandi, D. M., \& Kurniawan, A. (2018). Development of salt production technology using prism greenhouse method. In IOP Conference Series: Earth and Environmental Science (Vol. 106, No. 1, p. 012082). IOP Publishing.

8. Guntur, G., Jaziri, A. A., Prihanto, A. A., Arisandi, D. M., \& Kurniawan, A. (2018). Development of salt production technology using prism greenhouse method. In IOP Conference Series: Earth and Environmental Science (Vol. 106, No. 1, p. 012082). IOP Publishing.

9. Helmi, A., \& Sasaoka, M. (2018). Dealing with socioeconomic and climate-related uncertainty in small-scale salt producers in rural Sampang, Indonesia. Journal of rural studies, 59, 88-97.

10. Kerdan, I. G., Jalil-Vega, F., Toole, J., Gulati, S., Giarola, S., \& Hawkes, A. (2019). Modelling cost-effective pathways for natural gas infrastructure: A southern Brazil case study. Applied Energy, 255, 113799.

11. Krugman, P. R., \& Maurice, O. (2005). International Economics: Theory and Policy. Pearson International Edition.

12. Liu, W., Zhang, X., Fan, J., Li, Y., \& Wang, L. (2020). Evaluation of potential for salt cavern gas storage and integration of brine extraction: cavern utilization, Yangtze River Delta region. Natural Resources Research, 29(5), 3275-3290.

13. Mankiw, N. G. (2006). Pengantar Ekonomi Mikro. Jakarta: Salemba Empat.

14. Muhandhis, I., Susanto, H., \& Asfari, U. (2019). Development of System Dynamics Model to Increase Salt Fulfillment Ratio. Procedia Computer Science, 161, 867-875.

15. Nayar, K. G., Fernandes, J., McGovern, R. K., Dominguez, K. P., McCance, A., \& Al-Anzi, B. S. (2019). Cost and energy requirements of hybrid RO and ED brine concentration systems for salt production. Desalination, 456, 97-120.

16. Ningrum, I. H., Irianto, H., \& Riptanti, E. W. (2018, March). Analysis of soybean production and import trends and its import factors in Indonesia. In IOP 
Conference Series: Earth and Environmental Science (Vol. 142, No. 1, p. 012059). IOP Publishing.

17. Orazem, P. F. (2011). Production, Consumption, and Import Linkages Sugar in OECD. Journal of Agricultural Economics, 6(4). 31-52.

18. Peng, T., Ou, X., Yan, X., \& Wang, G. (2019). Life-cycle analysis of energy consumption and GHG emissions of aluminium production in China. Energy Procedia, 158, 3937-3943.

19. Pratama, R. A., \& Widodo, T. (2020). The Impact of Nontariff Trade Policy of European Union Crude Palm Oil Import on Indonesia, Malaysia, and the Rest of the World Economy: An Analysis in GTAP Framework. Jurnal Ekonomi Indonesia, 9(1), 39-52.

20. Purwanti, P., Susilo, E., \& Indrayani, E. (2020). Business Empowerment Program and Household Economic Welfare: Lesson from Indonesia. The Journal of Asian Finance, Economics, and Business, 7(1), 313-320.

21. Rusdi, R. (2018). The effect factors of supply salt in Indonesia. Scientific Journal of Reflection: Economic, Accounting, Management and Business, 1(2), 141-150.

22. Samir, S., \& Saleh, S. (2018). The Impact of Antidumping Policy of US Biodiesel Import on Indonesia and Argentina Economy-A General Equilibrium Analysis. International Journal of Social Science and Humanity, 8(12).

23. Santos, J. A., McKenzie, B., Trieu, K., Farnbach, S., Johnson, C., Schultz, J., ... \& Webster, J. (2019). Contribution of fat, sugar and salt to diets in the Pacific Islands: A systematic review. Public health nutrition, 22(10), 1858-1871.

24. Sinaga, M. S. (2018). Analysis of Influence of Tariff of Import Duty, Exchange Rate, Import Value And Import Volume on Income of Import Duty In Indonesia With Free Trade Agreement (FTA) As Moderating Variable. International Journal of Public Budgeting, Accounting and Finance, 1(2), 8-8.

25. Sudaryana, B., \& Pramesti, P. (2018). The strategy of welfare improvement for salt farmers in Indonesia. In MATEC Web of Conferences (Vol. 150, p. 05062). EDP Sciences.

26. Sudaryana, B., \& Pramesti, P. (2018). The strategy of welfare improvement for salt farmers in Indonesia. In MATEC Web of Conferences (Vol. 150, p. 05062). EDP Sciences.

27. Sulistyaningsih, T., \& Alighiri, D. (2018, March). Quality monitoring of salt produced in Indonesia through seawater evaporation on HDPE geomembrane lined ponds. In Journal of Physics: Conference Series (Vol. 983, No. 1, p. 012166). IOP Publishing.

28. Wang, T., Li, J., Jing, G., Zhang, Q., Yang, C., \& Daemen, J. J. (2019). Determination of the maximum allowable gas pressure for an underground gas storage salt cavern-A case study of Jintan, China. Journal of Rock Mechanics and Geotechnical Engineering, 11(2), 251-262.

29. Warsito, B., \& Triadi Putranto, T. (Eds.). (2020, November). Microplastic pollution from sea salt: its effect on public health and prevention alternatives-a review. In E3S Web of Conferences (Vol. 202, p. 06018). EDP Sciences. 
30. Yani, A. A., Herawati, N., Hajar, M. A. I., Thara, T., Hans, A., \& Hidayat, A. R. (2019, October). Environmental and social policy analysis on traditional salt production in Jeneponto Regency, Indonesia. In IOP Conference Series: Earth and Environmental Science (Vol. 343, No. 1, p. 012091). IOP Publishing. 